\title{
AN EMPIRICAL TEST OF THE INTERACTION BETWEEN REGIONAL FINANCIAL MARKETS AND REGIONAL GROWTH
}

\author{
Orley M. Amos, Jr., Majid Kermani, and John R. Wingender*
}

\begin{abstract}
Two models of the interaction between regional financial markets and regional production are examined. The first assumes that regional expenditures are determined by the regional interest rate, analogous to national IS-LM macroeconomic models. The second assumes that regional expenditures are constrained by the availability of regional credit available through financial markets. The first model implies regional financial markets have no effect on regional growth if financial capital is perfectly mobile. However, the second model indicates regional growth is affected by regional financial markets. This difference is tested using gross product and commercial bank loan data for states from 1965 to 1985. A two-step procedure is used that (1) estimates the structural coefficients for each state through time series analysis, then (2) tests the explenatory power of these coefficients in a cross-section analysis of state growth rates. This analysis indicates that regional financial markets exhibit a positive impact on regional growth.
\end{abstract}

\section{INTRODUCTION}

Analyses of regional financial markets by Moore and Hill (1982), Dow (1987), and Harrigan and McGregor (1987) suggest, contrary to conventional assumptions, that imperfect mobility of financial capital places constraints on the growth of regional economies. This is in contrast to most regional analyses that assume financial capital is extremely, if not perfectly, mobile among regions. The assumption of perfectly mobile financial capital implies that less mobile physical capital, natural resources, and labor are more important constraints to regional growth and thus more deserving of study.

Recent trends in bank closings in the United States provide insight into the question of financial capital mobility. Between 1982 and 1988, 807 banks were closed by the Federal Deposit Insurance Corporation in the 50 states. ${ }^{1}$ Texas led the way with 217 bank closings, followed by Oklahoma with 92 and Kansas with 50. These three states, contiguously located in the south central plains, accounted for $\mathbf{4 4 . 5}$ percent of the total. In contrast, there were 10 states, primarily located in the east, that experienced no bank closings during this period.

\footnotetext{
- Professor of Economics, Oklahoma State University; ECI Export-Import Co., Tehran, Iran; and Professor of Finance, Oklahoma State University, respectively. This paper was presented at the Southern Economic Association Meetings, New Orleans, Louisiana, November 19, 1990, and was funded by the University Center for Energy Research, Oklahoma State University.
} 
The regional differentiation of bank closings could be attributed to exogenously induced declines in the energy and agricultural sectors that dominate economies in the central part of the country. However, a contributing factor may have been constraints on financial capital mobility. Generalization of this analysis suggests that financial capital plays a more pervasive role in determining growth of a regional economy than conventionally assumed.

The objective of this study is to empirically test for the role of financial capital in the growth of regional economies. This is undertaken by first exploring two altemative models of the interaction between financial capital and regional production activity. The first model suggests a limited role for financial capital, and the second indicates financial capital is a key constraint on regional production. An empirical analysis is then conducted with state product and credit data from 1965 to 1985.

\section{THE THEORY OF REGIONAL FINANCIAL MARKETS}

A small number of studies have explicitly considered regional constraints on the flow of financial capital. Beare (1976), Fishkind (1977), and Garrison and Chang (1979) laid the foundations by considering the spatial differentiation of financial activity. Although they assumed that financial capital was perfectly mobile, their analyses of the regional impact of national monetary policy opened the doors for a formal theory of regional financial markets.

Roberts and Fishkind (1979) were the first to explicitly discuss the theory of regional financial markets, arguing that they exist due to differences in attitudes regarding risk, preferences pertaining to asset holdings, and information availability, all of which generate regional interest rate differentials. They also suggested that interest rate differentials are systematically related to the proximity of regional financial markets to national financial centers.

The model of regional financial markets was further enhanced by Moore and Hill (1982), who used a standard money multiplier analysis to illustrate how regional economic activity, and the subsequent demand for financial deposits, determines the availability of regional credit. In their model, the supply of regional credit is used to satisfy local demand with excess credit invested in national financial markets. Moreover, if regional credit demand exceeds the available supply, the regional financial market acts as a wholesaler, buying funds from the national financial market and, with an appropriate mark-up, supplying them to meet local demands.

Dow (1987) reinterpreted Moore and Hill's model by reversing the direction of causality. In contrast to Moore and Hill, Dow argued that the credit demanded 
in the regional financial market determines the amount of deposits needed for a given level of income. Dow used this interpretation to lay the groundwork for analyzing the impact of changes in the confidence level in the region brought about by an expanding or contracting economy.

The analyses by Moore and Hill and Dow suggest the importance of regional financial markets in promoting and/or limiting regional growth. In a growing region, with a relatively high demand for credit, the regional financial market supplies both local credit and credit from national markets. However, in a less prosperous region, with very little credit demand and a relatively low regional interest rate, the regional financial market redirects local funds to the national financial market and a relatively higher interest rate. A declining region, with relatively little credit demand and thus a low regional interest rate, will lose its local credit to the national financial market. Moreover, the lack of credit inhibits growth in the region and further constrains credit demand as the region spirals downward.

Harrigan and McGregor (1987) presented an expanded, more general model of regional financial markets that incorporates the two polar cases of regional financial activity-market segmentation and perfect financial capital mobility. Their model suggests how a declining region experiences cumulatively reinforcing problems and how local economies can have different degrees of market segmentation and spatial financial interaction.

Extending the earlier work of Moore and Hill (1982), Moore, Karaska, and Hill (1985) examined the interaction between regional finance and regional income, deriving a Keynesian-type regional income multiplier that incorporates the relationship between regional income and the supply of regional credit. The supply of regional credit, by augmenting regional consumption expenditures, generates a greater regional income multiplier than traditionally identified. Moore, Karaska, and Hill emphasize the mutual interaction between income and credit and provide an important foundation for the analysis of regional financial markets and regional growth undertaken here.

An extension of the Moore, Karaska, and Hill study was undertaken by Amos and Wingender (1993). They synthesized the Moore, Karaska, and Hill analysis with the Harrigan and McGregor model of regional financial markets, providing an analysis that considers the reinforcing interaction between regional financial markets and regional economic activity.

In one of the few studies addressing the passive/active nature of financial capital, Agu (1986) indicated that financial institutions can be either demand-following or supply-leading. The former is characterized by financial activity that passively responds to growth stimulated by other factors, and the latter is characterized by growth that is directly stimulated through the financial sector. Agu con- 
cluded that financial activity in Nigeria is demand-following, but he indicated that changes in the banking system could generate a supply-leading situation.

Two models are described in this paper. The first is a traditional Keynesian IS-LM model, while the second is a monetarist-based model of regional financial and economic interaction. An empirical analysis, presented in Section IV, indicates the significance of regional financial markets.

\section{TWO MODELS OF REGIONAL FINANCIAL MARKETS ${ }^{2}$}

The potential role played by financial activity in regional growth is seen by examining two alternative models originally developed in Amos and Wingender (1993). The first model is a modified IS-LM analysis, in which the regional interest rate is the key variable affecting regional expenditures. The second model assumes that the net availability of regional credit constrains regional expenditures.

\section{Interest Rate Induced Model (Model I)}

The first model is a modified IS-LM analysis, divided into a regional financial market submodel, which builds on the Harrigan and McGregor (H-M) analysis, and a Keynesian-type regional income submodel, which builds on the Moore, Karaska, and Hill (M-K-H) analysis. Equations (1) - (7) specify model I.

\section{Regional Financial Market Submodel:}

$$
\begin{aligned}
& C R_{t}^{d}=\lambda-\delta_{1} i_{t}+\delta_{2} Y_{t}+v\left[\left(i^{n}-\mu\right)-i_{t}\right] \\
& C R_{t}^{s}=\phi+\sigma_{1} i_{t}+\sigma_{2} Y_{t}+\tau\left[i_{t}-\left(i^{n}+\mu\right)\right] \\
& C R_{t}^{s}=C R_{t}^{d}
\end{aligned}
$$

Regional Production Submodel:

$$
\begin{aligned}
& C_{t}=\alpha+\beta_{1} Y_{t-1}-\beta_{2} i_{t} \\
& I_{t}=\gamma+\kappa_{1} Y_{t-1}-\kappa_{2} i_{t} \\
& M_{t}=\varphi+\omega_{1} Y_{t-1}-\omega_{2} i_{t} \\
& Y_{t}=C_{t}+I_{t}+X_{t}-M_{t}
\end{aligned}
$$

where: $\mathbf{C R}_{t}{ }_{t}=$ total regional demand for credit, including demand originating from regional and national sources, $\mathbf{C R}_{\mathrm{t}}^{\mathrm{s}}=$ total regional supply of credit, includ- 
ing supply originating from regional and national sources, $i_{t}=$ regional interest rate, $i^{n}=$ national interest rate, $Y_{t}=$ regional income, $C_{t}=$ regional consumption expenditures, $I_{t}=$ regional investment expenditures, $X_{t}=$ regional exports, $M_{t}=$ regional imports, and $\mathrm{t}=$ time.

The key parameters of the model are the effect of the regional interest rate $\left(\delta_{1}\right)$ and income $\left(\delta_{2}\right)$ on regional sources of credit demand, the effect of the regional interest rate $\left(\sigma_{1}\right)$ and income $\left(\sigma_{2}\right)$ on regional sources of credit supply, the effect of the differential between regional and national interest rates on national sources of credit demand $(v)$ and credit supply $(\tau)$, the arbitrage surcharge between national and regional financial markets $(\mu)$, the marginal propensities to consume $\left(\beta_{1}\right)$, invest $\left(K_{1}\right)$, and import $\left(\omega_{1}\right)$, and the induced effect of the regional interest rate on consumption $\left(\beta_{2}\right)$, investment $\left(k_{2}\right)$, and imports $\left(\omega_{2}\right)$. These parameters are all assumed to be positive. The intercept terms $(\lambda, \phi, \alpha, \gamma$, and $\varphi)$ have no such constraint.

Solving Equations (1) - (7) yields:

$$
\begin{aligned}
Y_{t}= & \frac{\alpha+\gamma-\varphi+X_{t}-\left[\left(\beta_{2}+\alpha_{2}-\omega_{2}\right) /\left(\delta_{1}+v+\sigma_{1}+\tau\right)\right]\left[\lambda-\phi+\psi\left(i^{n}-\mu\right)+\tau\left(i^{n}+\mu\right)\right]}{1+\left(\beta_{2}+\alpha_{2}-\omega_{2}\right)\left[\left(\delta_{2}-\sigma_{2}\right) /\left(\delta_{1}+v+\sigma_{1}+\tau\right)\right]} \\
& +\left[\frac{\beta_{1}+\alpha_{1}-\omega_{1}}{1+\left(\beta_{2}+\alpha_{2}-\omega_{2}\right)\left[\left(\delta_{2}-\sigma_{2}\right) /\left(\delta_{1}+v+\sigma_{1}+\tau\right)\right]}\right] Y_{t-1}
\end{aligned}
$$

Equation (8) is a first-order difference equation of the form: ${ }^{3}$

$$
Y_{t}=\Pi_{l}+\theta_{l} Y_{t-1}
$$

where:

$$
\Pi_{I}=\frac{\alpha+\gamma-\varphi+X_{1}-\left[\left(\beta_{2}+\kappa_{2}-\omega_{2}\right) /\left(\delta_{1}+v+\sigma_{1}+\tau\right)\right]\left[\lambda-\varphi+v\left(i^{n}-\mu\right)+\tau\left(i^{n}+\mu\right)\right]}{1+\left(\beta_{2}+\alpha_{2}-\omega_{2}\right)\left[\left(\delta_{2}-\sigma_{2}\right) /\left(\delta_{1}+v+\sigma_{1}+\tau\right)\right]}
$$

and

$$
\Theta_{1}=\frac{\beta_{1}+\alpha_{1}-\omega_{1}}{1+\left(\beta_{2}+\alpha_{2}-\omega_{2}\right)\left[\left(\delta_{2}-\sigma_{2}\right) /\left(\delta_{1}+v+\sigma_{1}+\tau\right)\right]}
$$


Equation (11) indicates the relative importance of regional production and regional financial activity to growth. The numerator $\beta_{1}+k_{1}-\omega_{1}$ is the standard, direct multiplicative effect of income on itself, including consumption, investment, and imports. ${ }^{4}$ The denominator includes three terms that capture the indirect multiplicative effect of income operating through the regional financial market. The first term $\left(\beta_{2}+K_{2}-\omega_{2}\right)$ indicates the combined effect of interest rate changes on income through the stimulation of consumption, investment, and imports. The second term $\left(\delta_{2}-\sigma_{2}\right)$ is the differential effect of regional income on credit demand and supply. The third term $\left(1 /\left(\delta_{1}+v+\sigma_{1}+\tau\right)\right)$ indicates the combined effect of changes in credit on the interest rate.

Although $\tau$ and $v$ are assumed to be constant, if they are endogenized, approaching infinity for larger values of credit as suggested by the H-M model, then the expression $1 /\left(\delta_{1}+v+\sigma_{1}+\tau\right)$ approaches zero, indicating that the denominator of $\theta_{1}$ approaches one and $\theta_{1}$ approaches $\beta_{1}+k_{1}-\omega_{1}$. This result clearly implies that regional financial activity has no effect on regional income. All stimulation comes directly from the traditional income induced expenditure effect $\left(\beta_{1}+\kappa_{1}\right.$ $\left.\omega_{1}\right)$. Model I thus indicates that if there is perfect financial capital mobility, which exists if $\tau$ and $v$ approach infinity, then regional financial markets have no effect on regional growth.

\section{Credit Constrained Model (Model II)}

An altemative view of this process is possible by assuming that net regional credit availability, rather than the regional interest rate, is a determinant of regional expenditures. Although the regional financial market submodel remains unchanged, the Keynesian-type production submodel is modified slightly, as indicated by Equations (4a) - (7a):

Regional Production Submodel (Model II):

$$
\begin{aligned}
& C_{t}=\alpha+\beta_{1} Y_{t-1}+\beta_{2} * C R_{t}^{*} \\
& I_{t}=\gamma+\kappa_{1} Y_{t-1}+\kappa_{2} * C R_{t}^{*} \\
& M_{t}=\varphi+\omega_{1} Y_{t-1}+\omega_{2} * C R_{t}^{*} \\
& Y_{t}=C_{t}+I_{t}+X_{t}-M_{t}
\end{aligned}
$$

The primary change in model II is substitution of the regional interest rate (it) with the term $C_{t^{*}}{ }^{*}$, defined as the net amount of additional credit available to the regional economy for expenditures. This model indicates that regional participants utilize two sources of funds for expenditures: income and credit. In this case, 
credit is defined as a flow rather than stock variable, indicating the amount of borrowed funds, in addition to income, that regional households and businesses use to undertake expenditures. ${ }^{5}$ As indicated by the positive signs for each parameter $\left(\beta_{2} *, K_{2}^{*}\right.$, and $\left.\omega_{2}^{*}\right)$, net credit availability has a positive impact on expenditures.

Solving Equations (1) - (3) and (4a) - (7a) yields an expression similar to Equation (8): 6

$$
\begin{aligned}
Y_{t}= & \frac{\alpha+\gamma-\varphi+X_{t}-\left(\beta_{2} *+\alpha_{2} *-\omega_{2}^{*}\right)\left[\lambda-\delta_{1}\left[\left(\lambda-\phi+v\left(i^{n}-\mu\right)+\tau\left(t^{*}+\mu\right)\right)\right] /\left(\delta_{1}+v+\sigma_{1}+\tau\right)\right]}{1-\left(\beta_{2}+\alpha_{2} *-\omega_{2} *\right)\left[\delta_{2}-\delta_{1}\left(\delta_{2}-\sigma_{2}\right) /\left(\delta_{1}+v+\sigma_{1}+\tau\right)\right]} \\
& +\left[\frac{\beta_{1}+x_{1}-\omega_{1}}{1-\left(\beta_{2} *+\alpha_{2} *-\omega_{2} *\right)\left[\delta_{2}-\delta_{1}\left(\delta_{2}-\sigma_{2}\right) /\left(\delta_{1}+v+\sigma_{1}+\tau\right)\right]}\right] Y_{-1-1}
\end{aligned}
$$

The solution to Equation (12) is given by Equation (13):

$$
Y_{t}=A \Theta_{I I} t+\frac{\Pi_{I I}}{1-\Theta_{I I}}
$$

where the critical term On is specified as:

$$
\Theta_{I I}=\frac{\beta_{1}+\kappa_{1}-\omega_{1}}{1-\left(\beta_{2} *+\kappa_{2} *-\omega_{2} *\right)\left[\delta_{2}-\delta_{1}\left(\delta_{2}-\sigma_{2}\right) /\left(\delta_{1}+v+\sigma_{1}+\tau\right)\right]}
$$

Although Equations (11) and (14) are similar, there are key differences. The first term in the denominator of Equation (14) $\left(\beta_{2}{ }^{*}+\kappa_{2}{ }^{*}-\omega_{2}{ }^{*}\right)$ indicates the combined effect of regional credit on regional income. The minus sign indicates that larger values reduce the denominator and increase On. This occurs because model II assumes that the net availability of credit, rather than the interest rate, stimulates production activity. In model I, additional credit demand inhibits regional activity by increasing the regional interest rate. In model II, additional credit demand stimulates regional activity.

The most important difference between models I and II is seen by endogenizing $\tau$ and $v$. In model $I$, if $\tau$ and $v$ approach infinity as the quantity of credit increases, then $\theta_{1}$ approaches $\beta_{1}+\kappa_{1}-\omega_{1}$, indicating that regional financial activity has no effect on regional growth. However, in model II, if $\tau$ and $v$ approach infinity, then $\Theta_{I I}$ approaches $\left(\beta_{1}+k_{1}-\omega_{1}\right) /\left[1-\left(\beta_{2}^{*}+k_{2}^{*}-\omega_{2}^{*}\right) \delta_{2}\right]$. Even with perfectly mobile financial capital, an important role of regional financial markets exists. 
Given these two models, the next step is to undertake an empirical test of the relationship between regional financial markets and regional production.

\section{EMPIRICAL TEST}

The preceding analysis generates the hypothesis that regional financial markets contribute to regional growth. This hypothesis is tested using gross production and credit data for states from 1965 to 1985 . A two-step process is undertaken to test the hypothesis. The first step is estimation of structural coefficients, which indicates the following: (1) the direct production multiplier effect [the numerators of Equations (11) and (14)]; and (2) the indirect multiplier effect through the regional financial markets [the denominators of Equations (11) and (14)]. The second step is a test of the explanatory power that these coefficients have with respect to regional growth.

The first step is undertaken by estimating the following equations:

$$
\begin{aligned}
Y_{i t}= & x_{i}+\psi_{1 i} Y_{i t-1}+\psi_{2 i} Y_{i t-2}+\eta_{0 i} C R_{i t}+\eta_{1 i} C R_{i t-1}+\eta_{2 i} C R_{i t-2} \\
& +\zeta_{i j} Z_{i j t}+e_{i t} \\
C R_{i t}= & \varpi_{i t}+\rho_{0 i} Y_{i t}+\rho_{1 i} Y_{i t-1}+\rho_{2 i} Y_{i t-2}+\varepsilon_{i k} X_{i t t}+u_{i t}
\end{aligned}
$$

where: $Y_{i t}=$ gross state product in state $i$ and year $t_{,} C R_{i t}=$ the amount of credit (net loans) by commercial banks in state $i$ and year $t_{1}^{7} Z_{i j t}=a$ set of $j$ independent variables explaining state economic activity, $X_{i k t}=a$ set of $k$ independent variables explaining state credit activity, and $\mathrm{e}_{i t}, \mathrm{u}_{i t}$ are error terms. Since the multiplicative relationship between gross state product and credit is not expected to occur within a single year, both terms are lagged two years in Equations (15) and (16). The set of coefficients for all lags of a given variable are summed to identify its total effect $\left(\psi_{i}=\psi_{1} i+\psi_{2 i}, \eta_{i}=\eta_{0 i}+\eta_{1 i}+\eta_{2 i}\right.$, and $\left.\rho_{i}=\rho_{0 i}+\rho_{1 i}+\rho_{2 i}\right)$.

Equations (15) and (16) are estimated for each state using time series data from 1965 to $1985 .^{8}$ The estimated coefficients then are used in a cross-section analysis to explain the growth rate in each state over this period.

The second step of this analysis is estimation of the cross-section equation that has the following general form:

$$
G R_{i}=a+b \psi_{i}+c \eta_{i p_{i}}+d_{h} W_{i h}+w_{i}
$$


where: $G_{\mathrm{i}}=$ the average annual growth rate for state $i$ for the period 1965 to 1985, $W_{\text {ih }}=a$ set of $h$ independent variables that are also expected to explain part of the variation in state growth rates, and $w_{i}=$ an error term. The first independent variable $\left(\Psi_{i}\right)$ is the direct production effect, and the second independent variable $\left(\eta_{i} p_{i}\right)$ is the indirect financial market effect. It is hypothesized that $b>0$ and c $>0$, indicating support for the hypothesis that regional financial markets contribute to regional economic growth. In particular, positive and statistical significance for $\mathrm{c}$ indicates that activity in regional financial markets plays a role in explaining regional growth, consistent with either model II or imperfect capital mobility in model I. Lack of statistical significance for $\mathrm{c}$ indicates that model I, with (near) perfect mobility of financial capital, is an appropriate explanation of regional economic activity and would lead to rejection of the hypothesis.

Tables 1 and 2 present estimates of Equations (15) and (16), respectively, for selected southern states. ${ }^{9}$ The two $\mathrm{Z}_{\mathrm{ijt}}$ independent variables included in Equation (15) are the percentage of manufacturing employment (PME) and the unemployment rate (UNR). PME is included to capture long-term structural changes in the state economies that might affect regional growth. In contrast, UNR is included to adjust for short-term business cycle fluctuations that are expected to affect a state's growth rate. The two $\mathrm{X}_{\mathrm{ikt}}$ independent variables included in Equation (16) are gross state product generated by the banking sector (BN), lagged two years, and the prime interest rate (INTR). Adjusted $\mathbf{R}^{2} \mathbf{s}$ for all but two of the 50 estimates of Equation (15) are above 0.99. $\mathbf{R}^{2} \mathrm{~s}$ for Alaska and North Dakota are between 0.98 and 0.99 . At least one of the lagged credit variables proved statistically significant in $\mathbf{2 6}$ of the 50 equations, with the lagged gross state product term statistically significant in all but seven equations. $\mathbf{R}^{2} \mathbf{s}$ for the estimates of Equation (16) are slightly lower than Equation (15). However, all but one are above 0.90 , and 34 are greater than 0.99 . At least one lag for gross state product is statistically significant in all but six of the estimates. Thus, estimates of Equations (15) and (16) provide a solid basis upon which to test the hypothesis generated from Equation (17).

Equation (17) is estimated after taking account of potential regional differences among the 50 states. The states are divided into four regions-Northeast, Midwest, South, and West. ${ }^{10}$ The intercept term in Equation (17) is replaced with four zero-one intercept dummy variables for the four regions. These are designated $a_{1}$-Northeast, $a_{2}$-Midwest, $a_{3}-$ South, and $a_{4}$-West. The variables $\psi$ and $\eta p$ are treated in a similar manner. However, rather than zero-one intercept dummy variables, they are zero-"value" slope dummy variables. They assume the value of the variable if the observation lies in the region but are zero otherwise. These variables are designated $\psi_{1}, \eta p_{1}-$ Northeast, $\psi_{2}, \eta p_{2}-$ Midwest, $\psi_{3}, \eta p_{3}-$ South, and $\psi 4, \eta p_{4}-W e s t$. Three $W_{\text {in }}$ were also used to explain the growth rates-the per- 
TABLE 1

Estimated Equations for Gross State Product $\left(Y_{i t}\right)$ for Selected States: 1965-1985 (t-Statistics)

\begin{tabular}{|c|c|c|c|c|c|c|c|c|c|}
\hline TATE & Constent & $Y_{t-1}$ & $Y_{t-2}$ & CR & $\mathrm{CR}_{\mathrm{t}-1}$ & $\mathrm{CR}_{\mathrm{t}-2}$ & PME & UNR & $\mathbf{R}^{2}$ \\
\hline $\mathbf{L}$ & $\begin{array}{r}-10054.6 \\
(-0.903)\end{array}$ & $\begin{array}{r}-0.073 \\
(-0.270)\end{array}$ & $\begin{array}{r}0.720 \\
(3.022)\end{array}$ & $\begin{array}{r}1.273 \\
(3.332)\end{array}$ & $\begin{array}{r}-0.072 \\
(-0.106)\end{array}$ & $\begin{array}{r}0.851 \\
(1.655)\end{array}$ & $\begin{array}{r}317.7 \\
(0.984)\end{array}$ & $\begin{array}{r}47.8 \\
(0.239)\end{array}$ & .999 \\
\hline $\mathbf{A R}$ & $\begin{array}{r}-9957.2 \\
(-1.325)\end{array}$ & $\begin{array}{r}-0.274 \\
(-0.811)\end{array}$ & $\begin{array}{r}0.411 \\
(1.856)\end{array}$ & $\begin{array}{r}0.580 \\
(0.897)\end{array}$ & $\begin{array}{r}1.611 \\
(1.661)\end{array}$ & $\begin{array}{r}1.196 \\
(0.958)\end{array}$ & $\begin{array}{r}342.2 \\
(1.523)\end{array}$ & $\begin{array}{r}40.5 \\
(0.310)\end{array}$ & .998 \\
\hline FL & $\begin{array}{r}55083.8 \\
(2.834)\end{array}$ & $\begin{array}{r}0.646 \\
(2.485)\end{array}$ & $\begin{array}{r}0.625 \\
(2.092)\end{array}$ & $\begin{array}{r}-0.217 \\
(-2.121)\end{array}$ & $\begin{array}{r}-0.135 \\
(-1.556)\end{array}$ & $\begin{array}{r}-0.134 \\
(-1.511)\end{array}$ & $\begin{array}{r}-3125.4 \\
(-2.718)\end{array}$ & $\begin{array}{r}-1918.5 \\
(-3.457)\end{array}$ & .999 \\
\hline GA & $\begin{array}{l}8002.8 \\
(0.870)\end{array}$ & $\begin{array}{r}0.341 \\
(1.394)\end{array}$ & $\begin{array}{r}0.616 \\
(2.551)\end{array}$ & $\begin{array}{r}0.645 \\
(1.908)\end{array}$ & $\begin{array}{r}-1.571 \\
(-3.280)\end{array}$ & $\begin{array}{r}2.329 \\
(3.271)\end{array}$ & $\begin{array}{r}-185.9 \\
(-0.671)\end{array}$ & $\begin{array}{l}-1160.5 \\
(-3.135)\end{array}$ & .999 \\
\hline KY & $\begin{array}{l}9175.3 \\
(0.835)\end{array}$ & $\begin{array}{r}0.785 \\
(1.915)\end{array}$ & $\begin{array}{r}0.757 \\
(1.913)\end{array}$ & $\begin{array}{r}0.622 \\
(0.646)\end{array}$ & $\begin{array}{r}-1.155 \\
(-0.793)\end{array}$ & $\begin{array}{r}-0.850 \\
(-0.509)\end{array}$ & $\begin{array}{r}-292.1 \\
(-0.838)\end{array}$ & $\begin{array}{r}-636.0 \\
(-3.046)\end{array}$ & .998 \\
\hline LA & $\begin{array}{r}18700.3 \\
(0.788)\end{array}$ & $\begin{array}{r}1.334 \\
(7.865)\end{array}$ & $\begin{array}{r}-0.666 \\
(-2.660)\end{array}$ & $\begin{array}{r}3.727 \\
(2.877)\end{array}$ & $\begin{array}{r}-3.866 \\
(-1.950)\end{array}$ & $\begin{array}{r}1.780 \\
(0.864)\end{array}$ & $\begin{array}{r}-584.9 \\
(-0.474)\end{array}$ & $\begin{array}{r}-1620.4 \\
(-2.077)\end{array}$ & .996 \\
\hline MS & $\begin{array}{r}15024.1 \\
(1.974)\end{array}$ & $\begin{array}{r}-0.646 \\
(-2.039)\end{array}$ & $\begin{array}{r}0.572 \\
(2.053)\end{array}$ & $\begin{array}{r}5.434 \\
(3.857)\end{array}$ & $\begin{array}{r}-6.245 \\
(-2.336)\end{array}$ & $\begin{array}{r}5.019 \\
(2.999)\end{array}$ & $\begin{array}{r}-387.0 \\
(-1.803)\end{array}$ & $\begin{array}{r}-414.1 \\
(-2.203)\end{array}$ & .998 \\
\hline NC & $\begin{array}{r}37931.2 \\
(2.370)\end{array}$ & $\begin{array}{r}0.807 \\
(2.015)\end{array}$ & $\begin{array}{r}0.317 \\
(0.669)\end{array}$ & $\begin{array}{r}1.195 \\
(2.697)\end{array}$ & $\begin{array}{r}-1.898 \\
(-1.746)\end{array}$ & $\begin{array}{r}0.041 \\
(0.037)\end{array}$ & $\begin{array}{r}-844.8 \\
(-2.306)\end{array}$ & $\begin{array}{r}-398.9 \\
(-1.576)\end{array}$ & .999 \\
\hline OK & $\begin{array}{r}-7600.1 \\
(-0.924)\end{array}$ & $\begin{array}{r}0.481 \\
(1.340)\end{array}$ & $\begin{array}{r}-0.888 \\
(-2.193)\end{array}$ & $\begin{array}{r}3.233 \\
(3.719)\end{array}$ & $\begin{array}{r}-0.896 \\
(-0.869)\end{array}$ & $\begin{array}{r}1.658 \\
(2.197)\end{array}$ & $\begin{array}{r}621.9 \\
(1.393)\end{array}$ & $\begin{array}{r}-121.3 \\
(-0.444)\end{array}$ & .999 \\
\hline SC & $\begin{array}{r}11468.0 \\
(1.250)\end{array}$ & $\begin{array}{r}0.348 \\
(1.084)\end{array}$ & $\begin{array}{r}0.819 \\
(2.436)\end{array}$ & $\begin{array}{r}-0.503 \\
(-1.024)\end{array}$ & $\begin{array}{r}-0.028 \\
(-0.042)\end{array}$ & $\begin{array}{r}0.387 \\
(0.487)\end{array}$ & $\begin{array}{r}-229.4 \\
(-1.120)\end{array}$ & $\begin{array}{r}-382.7 \\
(-2.498)\end{array}$ & .998 \\
\hline TN & $\begin{array}{r}10187.3 \\
(0.482)\end{array}$ & $\begin{array}{r}0.223 \\
(0.721)\end{array}$ & $\begin{array}{r}0.662 \\
(2.224)\end{array}$ & $\begin{array}{r}1.185 \\
(1.948)\end{array}$ & $\begin{array}{r}-1.132 \\
(-1.671)\end{array}$ & $\begin{array}{r}0.897 \\
(1.316)\end{array}$ & $\begin{array}{r}-247.1 \\
(-0.450)\end{array}$ & $\begin{array}{r}-465.0 \\
(-1.725)\end{array}$ & .999 \\
\hline TX & $\begin{array}{r}84286.8 \\
(2.205)\end{array}$ & $\begin{array}{r}1.749 \\
(9.633)\end{array}$ & $\begin{array}{r}-0.171 \\
(-0.570)\end{array}$ & $\begin{array}{r}-0.874 \\
(-1.173)\end{array}$ & $\begin{array}{r}-2.868 \\
(-3.747)\end{array}$ & $\begin{array}{r}3.046 \\
(3.776)\end{array}$ & $\begin{array}{l}-3245.6 \\
(-1.942)\end{array}$ & $\begin{array}{r}7531.4 \\
(-3.408)\end{array}$ & .998 \\
\hline VA & $\begin{array}{r}12151.7 \\
(1.925)\end{array}$ & $\begin{array}{r}0.692 \\
(2.511)\end{array}$ & $\begin{array}{r}0.400 \\
(1.320)\end{array}$ & $\begin{array}{r}0.578 \\
(1.496)\end{array}$ & $\begin{array}{r}-0.992 \\
(-1.653)\end{array}$ & $\begin{array}{r}0.429 \\
(0.628)\end{array}$ & $\begin{array}{r}-414.4 \\
(-1.852)\end{array}$ & $\begin{array}{r}-335.4 \\
(-0.981)\end{array}$ & .999 \\
\hline WA & $\begin{array}{r}29616.9 \\
(4.270)\end{array}$ & $\begin{array}{r}0.164 \\
(0.431)\end{array}$ & $\begin{array}{r}0.241 \\
(1.006)\end{array}$ & $\begin{array}{r}1.274 \\
(2.289)\end{array}$ & $\begin{array}{r}0.017 \\
(0.032)\end{array}$ & $\begin{array}{r}0.821 \\
(1.262)\end{array}$ & $\begin{array}{r}-950.8 \\
(-4.178)\end{array}$ & $\begin{array}{r}-623.8 \\
(-2.344)\end{array}$ & .999 \\
\hline wv & $\begin{array}{r}5732.6 \\
(1.327)\end{array}$ & $\begin{array}{r}0.287 \\
(0.737)\end{array}$ & $\begin{array}{r}0.089 \\
(0.313)\end{array}$ & $\begin{array}{r}0.655 \\
(1.125)\end{array}$ & $\begin{array}{r}-0.225 \\
(-0.267)\end{array}$ & $\begin{array}{r}1.810 \\
(2.088)\end{array}$ & $\begin{array}{r}-121.2 \\
(-0.835)\end{array}$ & $\begin{array}{r}-158.5 \\
(-1.610)\end{array}$ & .999 \\
\hline
\end{tabular}




\section{TABLE 2}

Estimated Equations for the Amount of Credit by Commercial Banks (CRit) for Selected States: 1965-1985

(t-Statistics)

\begin{tabular}{|c|c|c|c|c|c|c|c|c|c|}
\hline STATE & Constant & $\mathbf{Y}$ & $\mathbf{Y}_{t-1}$ & $\mathbf{Y}_{t-2}$ & $\mathrm{BN}$ & $\mathrm{BN}_{\mathrm{t}-1}$ & $\mathrm{BN}_{\mathrm{t}-2}$ & INTR & $\mathbf{R}^{2}$ \\
\hline AL & $\begin{array}{r}-563.0 \\
(-1.304)\end{array}$ & $\begin{array}{r}0.479 \\
(5.103)\end{array}$ & $\begin{array}{r}0.242 \\
(2.092)\end{array}$ & $\begin{array}{r}-0.362 \\
(-2.299)\end{array}$ & $\begin{array}{r}-6.081 \\
(-1.730)\end{array}$ & $\begin{array}{r}1.470 \\
(0.275)\end{array}$ & $\begin{array}{r}-1.772 \\
(-0.430)\end{array}$ & $\begin{array}{r}-63.207 \\
(-1.601)\end{array}$ & .997 \\
\hline $\mathbf{A R}$ & $\begin{array}{r}-249.5 \\
(-1.542)\end{array}$ & $\begin{array}{r}0.336 \\
(5.771)\end{array}$ & $\begin{array}{r}0.015 \\
(0.207)\end{array}$ & $\begin{array}{r}0.019 \\
(0.225)\end{array}$ & $\begin{array}{r}-0.667 \\
(-0.391)\end{array}$ & $\begin{array}{r}-1.868 \\
(-0.649)\end{array}$ & $\begin{array}{r}0.963 \\
(0.415)\end{array}$ & $\begin{array}{r}-45.319 \\
(-2.398)\end{array}$ & .998 \\
\hline FL & $\begin{array}{r}-3614.2 \\
(-0.565)\end{array}$ & $\begin{array}{r}0.404 \\
(0.623)\end{array}$ & $\begin{array}{r}1.630 \\
(1.539)\end{array}$ & $\begin{array}{r}-1.875 \\
(-1.329)\end{array}$ & $\begin{array}{r}-44.427 \\
(-2.362)\end{array}$ & $\begin{array}{l}18.555 \\
(0.701)\end{array}$ & $\begin{array}{r}21.200 \\
(1.287)\end{array}$ & $\begin{array}{r}818.300 \\
(0.716)\end{array}$ & .928 \\
\hline GA & $\begin{array}{l}1557.7 \\
(1.181)\end{array}$ & $\begin{array}{r}0.309 \\
(2.802)\end{array}$ & $\begin{array}{r}0.435 \\
(4.021)\end{array}$ & $\begin{array}{r}-0.295 \\
(-1.729)\end{array}$ & $\begin{array}{r}-10.189 \\
(-1.521)\end{array}$ & $\begin{array}{r}-0.944 \\
(-0.131)\end{array}$ & $\begin{array}{r}-7.026 \\
(-1.335)\end{array}$ & $\begin{array}{r}-37.829 \\
(-0.381)\end{array}$ & .997 \\
\hline $\mathbf{K Y}$ & $\begin{array}{r}-442.8 \\
(-0.817)\end{array}$ & $\begin{array}{r}0.349 \\
(3.168)\end{array}$ & $\begin{array}{r}0.231 \\
(2.081)\end{array}$ & $\begin{array}{r}-0.373 \\
(-2.264)\end{array}$ & $\begin{array}{r}1.829 \\
(0.715)\end{array}$ & $\begin{array}{r}1.378 \\
(0.378)\end{array}$ & $\begin{array}{r}0.132 \\
(0.047)\end{array}$ & $\begin{array}{r}-93.642 \\
(-2.196)\end{array}$ & .997 \\
\hline LA & $\begin{array}{r}28.5 \\
(0.027)\end{array}$ & $\begin{array}{r}0.232 \\
(3.992)\end{array}$ & $\begin{array}{r}-0.191 \\
(-2.024)\end{array}$ & $\begin{array}{r}0.157 \\
(1.702)\end{array}$ & $\begin{array}{r}3.344 \\
(0.587)\end{array}$ & $\begin{array}{l}-11.327 \\
(-1.427)\end{array}$ & $\begin{array}{l}11.364 \\
(2.050)\end{array}$ & $\begin{array}{r}3.164 \\
(0.023)\end{array}$ & .994 \\
\hline MS & $\begin{array}{r}-302.7 \\
(-1.522)\end{array}$ & $\begin{array}{r}0.158 \\
(2.692)\end{array}$ & $\begin{array}{r}0.215 \\
(3.081)\end{array}$ & $\begin{array}{r}0.002 \\
(0.021)\end{array}$ & $\begin{array}{r}-2.122 \\
(-0.955)\end{array}$ & $\begin{array}{r}2.414 \\
(0.674)\end{array}$ & $\begin{array}{r}-3.904 \\
(-1.491)\end{array}$ & $\begin{array}{r}-12.397 \\
(-0.567)\end{array}$ & .998 \\
\hline NC & $\begin{array}{r}-1459.6 \\
(-1.900)\end{array}$ & $\begin{array}{r}0.375 \\
(2.563)\end{array}$ & $\begin{array}{r}0.344 \\
(1.788)\end{array}$ & $\begin{array}{r}-0.081 \\
(-0.365)\end{array}$ & $\begin{array}{r}-19.747 \\
(-2.951)\end{array}$ & $\begin{array}{r}9.481 \\
(0.729)\end{array}$ & $\begin{array}{r}-20.188 \\
(-1.999)\end{array}$ & $\begin{array}{r}-100.621 \\
(-0.919)\end{array}$ & .991 \\
\hline OK & $\begin{array}{r}-672.2 \\
(-1.742)\end{array}$ & $\begin{array}{r}0.230 \\
(4.221)\end{array}$ & $\begin{array}{r}-0.053 \\
(-0.476)\end{array}$ & $\begin{array}{r}0.180 \\
(2.412)\end{array}$ & $\begin{array}{r}3.881 \\
(1.576)\end{array}$ & $\begin{array}{r}-5.574 \\
(-1.428)\end{array}$ & $\begin{array}{r}2.354 \\
(0.908)\end{array}$ & $\begin{array}{r}5.574 \\
(0.113)\end{array}$ & .999 \\
\hline SC & $\begin{array}{r}75.4 \\
(0.243)\end{array}$ & $\begin{array}{r}0.331 \\
(2.259)\end{array}$ & $\begin{array}{r}0.116 \\
(0.734)\end{array}$ & $\begin{array}{r}-0.183 \\
(-0.898)\end{array}$ & $\begin{array}{r}-2.957 \\
(-0.349)\end{array}$ & $\begin{array}{r}5.683 \\
(0.461)\end{array}$ & $\begin{array}{l}-12.891 \\
(-1.578)\end{array}$ & $\begin{array}{r}-104.857 \\
(-2.645)\end{array}$ & .981 \\
\hline TN & $\begin{array}{r}136.2 \\
(0.365)\end{array}$ & $\begin{array}{r}0.376 \\
(3.465)\end{array}$ & $\begin{array}{r}0.237 \\
(1.532)\end{array}$ & $\begin{array}{r}-0.450 \\
(-2.710)\end{array}$ & $\begin{array}{r}-1.227 \\
(-0.340)\end{array}$ & $\begin{array}{r}-2.544 \\
(-0.462)\end{array}$ & $\begin{array}{r}5.630 \\
(1.163)\end{array}$ & $\begin{array}{l}53.928 \\
(0.834)\end{array}$ & .994 \\
\hline TX & $\begin{array}{l}1217.6 \\
(0.362)\end{array}$ & $\begin{array}{r}0.083 \\
(1.030)\end{array}$ & $\begin{array}{r}-0.289 \\
(-2.092)\end{array}$ & $\begin{array}{r}0.310 \\
(2.395)\end{array}$ & $\begin{array}{r}9.993 \\
(2.276)\end{array}$ & $\begin{array}{l}-13.844 \\
(-2.273)\end{array}$ & $\begin{array}{l}18.605 \\
(4.409)\end{array}$ & $\begin{array}{r}-45.703 \\
(-0.122)\end{array}$ & .998 \\
\hline VA & $\begin{array}{r}224.7 \\
(0.241)\end{array}$ & $\begin{array}{r}0.379 \\
(1.728)\end{array}$ & $\begin{array}{r}0.518 \\
(1.470)\end{array}$ & $\begin{array}{r}-0.696 \\
(-1.746)\end{array}$ & $\begin{array}{l}-14.539 \\
(-2.651)\end{array}$ & $\begin{array}{l}15.747 \\
(1.119)\end{array}$ & $\begin{array}{r}-0.492 \\
(-0.046)\end{array}$ & $\begin{array}{r}-62.035 \\
(-0.463)\end{array}$ & .994 \\
\hline wV & $\begin{array}{r}-231.2 \\
(-0.830)\end{array}$ & $\begin{array}{r}0.881 \\
(4.548)\end{array}$ & $\begin{array}{r}-0.501 \\
(-1.958)\end{array}$ & $\begin{array}{r}-0.211 \\
(-0.986)\end{array}$ & $\begin{array}{r}3.823 \\
(1.636)\end{array}$ & $\begin{array}{r}-3.994 \\
(-1.454)\end{array}$ & $\begin{array}{r}3.568 \\
(1.770)\end{array}$ & $\begin{array}{r}-23.063 \\
(-0.972)\end{array}$ & .996 \\
\hline
\end{tabular}


centage of state population residing in metropolitan areas (METPOP), population density (DEN), and the percentage of U.S. farms in the state (FARM). These variables are designed to capture structural differences in the state economies.

The following is the cross-section estimate of the modified form of Equation (17), with t-values in parentheses:

$$
\begin{aligned}
& \mathrm{GR}=5.361 \mathrm{a}_{1}+9.100 \mathrm{a}_{2}+6.480 \mathrm{a}_{3}-1.472 \mathrm{a}_{4}+4.118 \psi_{1}+7.445 \mathrm{pp}_{1} \\
& \begin{array}{llllll}
(2.130) & (8.935) & (4.912) & (-0.402) & (1.772) & \text { (2.881) }
\end{array} \\
& +0.006 \psi_{2}-0.839 \eta p_{2}+1.935 \psi_{3}+1.548 \eta \rho_{3}+11.034 \psi_{4}+8.359 \eta \rho_{4} \\
& \begin{array}{lllll}
(0.007) & (-1.297) \quad(1.836) & (1.680) & (3.475) & (2.300)
\end{array} \\
& + \text { 0.024METPOP - 0.004DEN - 0.290FARM } \\
& \text { (2.420) } \quad(-3.144) \quad(-2.642) \\
& \text { Adjusted } R^{2}=0.497 \quad F(15,35)=4.464 \quad N=50
\end{aligned}
$$

The $\mathbf{R}^{2}$ indicates that about 50 percent of the growth rate variation is explained by the model. The F-value is statistically significant at the 0.05 level.

The $\eta p$ coefficients are statistically significant in three of the four regions. The midwest region is the only one without statistical significance. The coefficient for $\eta p_{2}$ also exhibits the wrong sign. The significant results exhibited by the other three regions provide support for the hypothesis that regional financial markets contribute to regional growth.

\section{v. POLICY IMPLICATIONS}

This study suggests that regional growth can be stimulated by appropriate policies directed through local financial markets. Contrary to conventional expectations, results indicate that financial credit is not a passive player in regional growth. Regional growth can be restricted by an inadequate supply of credit, and it can be stimulated by making credit more readily available to regional borrowers. In particular, states seeking to promote economic growth can look to financial markets, either directly increasing the supply of credit to borrowers or encouraging commercial banks to increase credit availability. A financial market- 
oriented growth strategy should be considered a viable addition to more traditional resource and output-based strategies historically pursued by states.

\section{SUMMARY AND CONCLUSIONS}

This analysis explores two models of the interaction between regional financial markets and regional growth. Model I, assuming that regional expenditures are induced by the interest rate, indicates that regional factor markets have no effect on regional growth if financial capital is perfectly mobile. Model II, assuming that regional expenditures are induced by the net availability of regional credit, implies a key role for regional factor markets, even if financial capital is perfectly mobile.

A test of the hypothesized role of regional financial markets is undertaken using gross product and credit data for states from 1965 to 1985 . Using a two-step process, coefficient estimates from time series regressions for each state are used in a cross-section analysis of average annual growth rates. Results indicate that financial activity is a significant factor explaining states' growth rates. Moreover, the indirect multiplicative effect of financial activity appears to be equally important to the direct production multiplier effect.

This analysis clearly indicates that regional financial activity is an important aspect of regional growth. It further suggests that financial capital is not as mobile between regions as conventionally assumed and implies that credit constraints, like labor, physical capital, and raw material constraints, must be considered in the analysis of regional economies.

\section{ENDNOTES}

1. Four bank closings in Puerto Rico are excluded from the total listed in the 1988 FDIC Annual Report.

2. This section summarizes the theoretical analysis presented in Amos and Wingender (1993), which contains a more extensive treatment of both models.

3. The solution to Equation (9) is given by:

$$
Y_{t}=A \Theta_{l} t+\frac{\Pi_{l}}{1-\theta_{l}}
$$

The stability is determined by $\theta_{1}$. If $\Theta_{I}=-1$, the growth path of $Y_{t}$ oscillates at a constant amplitude; if $-1<\Theta_{1}<0$, the amplitude is decreasing, and if $\Theta_{1}<-1$, the 
amplitude is increasing. If $\theta_{I}=1$, the growth path of $Y_{t}$ is monotonic and constant; if $0<\theta_{1}<1$, it is decreasing, and if $\theta_{I}>1$, it is increasing. It is not possible to unambiguously determine the sign of $\theta_{1}$, given that both the denominator and numerator can be negative or positive. The key consideration in determining the value of $\theta_{I}$ is a comparison of the numerator and denominator and the critical role played by regional financial markets.

4. This term is expected to be positive unless the marginal propensity to import is greater than the sum of the marginal propensities to consume and invest, an altemative that may be possible in an extremely resource poor region heavily dependent on imports. The numerator is also expected to be less than one unless the regional economy is experiencing an extraordinary period of growth attributable to agglomeration economies and/or increasing retums to scale.

5. In model I, the distinction between stock and flow in the regional financial market is unimportant since the critical determinant for production is the interest rate. However, in model $\mathrm{II}, \mathrm{CR}_{\mathrm{t}}^{*}$ is the net flow of funds or the change in corresponding stocks from one time period to the next.

6. $\mathrm{CR}_{\mathrm{t}}^{*}$ is the amount of credit demand for regional sources, exclusive of national sources: $\mathrm{CR}_{t^{*}}=\lambda-\delta_{1} \mathrm{i}_{\mathrm{t}}+\delta_{2} \mathrm{Y}_{\mathrm{t}}$. It is obtained by solving the regional financial model in Equations (1) - (3) for the equilibrium interest rate, then isolating the resulting credit demand from Equation (1) originating within the region.

7. $\mathbf{C R}_{\text {it }}$ includes only credit from commercial banks and omits regional credit sources such as savings and loan associations, credit unions, mutual savings banks, and finance companies. Because commercial banks dominated local credit markets during most of the 20-year period under analysis, these exclusions are not expected to materially affect the results.

8. Gross state product data are from computer disks obtained from the Bureau of Economic Analysis. Net loan data are obtained from selected editions of the U.S. Statistical Abstract and FDIC Annual Banking Statistics.

9. A complete list of equations for all $\mathbf{5 0}$ states is available from the authors upon request.

10. States in each region include: Northeast-Maine, New Hampshire, Vermont, Massachusetts, Rhode Island, Connecticut, New York, New Jersey, and Pennsylvania; Midwest-Ohio, Indiana, minois, Michigan, Wisconsin, Minnesota, Iowa, Missouri, North Dakota, South Dakota, Nebraska, and Kansas; SouthDelaware, Maryland, Virginia, West Virginia, North Carolina, South Carolina, Georgia, Florida, Kentucky, Tennessee, Alabama, Mississippi, Arkansas, Louisiana, Oklahoma, and Texas; and West-Washington, Oregon, California, Alaska, Hawaii, Montana, Idaho, Wyoming, Colorado, New Mexico, Arizona, Utah, and Nevada. 


\section{REFERENCES}

Amos, Orley M., and John R. Wingender. "A Model of the Interaction Between Regional Financial Markets and Regional Growth." Regional Science and Urban Economics 23 (1993). Forthcoming.

Agu, C. C. "Financial Institutions and Economic Development: The Experience of Nigeria." The South African Journal of Economics 54 (1986): 319-333.

Beare, John B. "A Monetarist Model of Regional Business Cycles." Journal of Regional Science 16 (1976): 57-63.

Dow, Sheila C. "The Treatment of Money in Regional Economics." Journal of Regional Science 27 (1987): 13-24

Fishkind, Henry H. "The Regional Impact of Monetary Policy: An Econometric Simulation Study of Indiana 1958-1973." Journal of Regional Science 17 (1977): 77-88.

Garrison, Charles G., and Hui S. Chang. "The Effect of Monetary and Fiscal Policies on Regional Business Cycles." International Regional Science Review 4 (1979): 167-180.

Harrigan, Frank J., and Peter G. McGregor. "Interregional Arbitrage and the Supply of Loanable Funds: A Model of Intermediate Financial Capital Mobility." Journal of Regional Science 27 (1987): 357-367.

Moore, Craig L., and Joanne M. Hill. "Interregional Arbitrage and the Supply of Loanable Funds." Journal of Regional Science 22 (1982): 499-512.

Moore, Craig L., Gerald J. Karaska, and Joanne M. Hill. "The Impact of the Banking System on Regional Analyses." Regional Studies 19 (1985): 29-35.

Roberts, R. Blaine, and Henry H. Fishkind. "The Role of Monetary Forces in Regional Economic Activity: An Econometric Simulation Analysis." Journal of Regional Science 19 (1979): 15-29. 